\title{
Convergence and Segregation of the Multiple Rod Pathways in Mammalian Retina
}

\author{
Béla Völgyi, ${ }^{1,2}$ Michael R. Deans, ${ }^{3}$ David L. Paul, ${ }^{3}$ and Stewart A. Bloomfield ${ }^{1,2}$ \\ Departments of ${ }^{1}$ Ophthalmology and ${ }^{2}$ Physiology and Neuroscience, New York University School of Medicine, New York, New York 10016, and \\ ${ }^{3}$ Department of Neurobiology, Harvard Medical School, Boston, Massachusetts 02115
}

Using a multidisciplinary approach, we demonstrate that three different pathways are responsible for the transmission of rod signals across the mouse retina. Each pathway serves a primarily nonoverlapping range of stimulus intensities, with ganglion cells receiving either segregated or convergent inputs. For both on-center $(\mathrm{ON})$ and off-center $(\mathrm{OFF})$ ganglion cells, the primary rod pathway carries signals with the lowest threshold, whereas the secondary rod pathway is less sensitive by $\sim 1 \log$ unit. In addition, OFF signaling uses a tertiary rod pathway that is $\sim 1$ log unit less sensitive than the secondary. Although some ganglion cells received rod inputs exclusively from one of the pathways, others showed convergent inputs. Using pharmacological and genetic approaches, we defined classes of $0 \mathrm{~N}$ and OFF ganglion cells for which the scotopic inputs derive only from the primary pathway or from both primary and secondary pathways. In addition, we observed a class of OFF ganglion cell receiving mixed input from primary and tertiary pathways. Interestingly, OFF ganglion cells receiving convergent inputs from all three rod pathways or from the secondary and tertiary pathways together were never observed. Overall, our data show a complex arrangement of convergence and segregation of rod inputs to ganglion cells in the mammalian retina.

Key words: convergence; gap junction; retina; retinal ganglion cell; rod; vision

\section{Introduction}

Together, rod and cone photoreceptors enable the retina to remain responsive over the 50 billion-fold change in ambient light intensity encountered in the transition from night to day. Rods and cones are presynaptic to different bipolar cells, thereby segregating their signals into parallel streams (Boycott and Dowling, 1969; Boycott and Kolb, 1973; Ghosh et al., 2004; Pignatelli and Strettoi, 2004). Whereas $>10$ morphological types of cone bipolar cell exist, only a single type of rod bipolar cell has been identified (Boycott and Wässle, 1991; Euler and Wässle, 1995). Although this would suggest that rod circuitry is relatively simple, it now is believed that multiple pathways transmit rod signals across the retina (for review, see Bloomfield and Dacheux, 2001).

In the primary rod pathway (see Fig. $1 A$ ), axon terminals of rod bipolar cells innervate AII amacrine cells, which, in turn, form sign-inverting chemical synapses with off-center (OFF) cone bipolar cells and sign-conserving electrical synapses with on-center (ON) cone bipolar cells (Famiglietti and Kolb, 1975; Dacheux and Raviola, 1986; Strettoi et al., 1990). Thus, opposite polarity rod-mediated signals use cone circuitry to reach ON or OFF ganglion cells. A second rod pathway is formed by the gap junctions connecting rod spherules and cone pedicles (Raviola and Gilula, 1973) (see Fig. 1B). Here, the rod signals are trans-

Received July 29, 2004; revised Nov. 2, 2004; accepted Nov. 2, 2004.

This study was supported by National Institutes of Health Grants EY07360 to S.A.B. and GM37751 and EY14127 to D.L.P. and a grant from Research to Prevent Blindness to the Department of Ophthalmology, New York University School of Medicine.

Correspondence should be addressed to Dr. Stewart A. Bloomfield, Department of Ophthalmology, New York University School of Medicine, 550 First Avenue, New York, NY 10016. E-mail: blooms01@med.nyu.edu.

D01:10.1523/JNEUROSCI.3096-04.2004

Copyright $\odot 2004$ Society for Neuroscience ～0270-6474/04/2411182-11\$15.00/0 mitted directly to cones and then to ganglion cells via cone bipolar cells (Nelson, 1977; Bloomfield and Miller, 1982; Dacheux and Raviola, 1982; Schneeweis and Schnapf, 1995).

Human psychophysical studies support the idea of two rod pathways: one carrying slow, low-threshold signals and a faster one with lower sensitivity (Blakemore and Rushton, 1965a,b; Connor, 1982). However, attempts to determine the targets of the different rod pathways have produced conflicting results. Several studies have suggested a division of labor whereby the primary and secondary rod pathways innervate different ganglion cell types (Müller et al., 1988; DeVries and Baylor, 1995; Deans et al., 2002). In contrast, Soucy et al. (1998) reported ganglion cells in mouse with mixed rod pathway inputs. It thus remains unclear whether the rod pathways remain segregated and/or converge onto cells in the inner retina.

The contribution of rod-cone junctions to the secondary rod pathway has been challenged by a study of mice genetically engineered to lack cone photoreceptors (Soucy et al., 1998). In these animals, the rod OFF responses survived blockade of the primary rod pathway. Because the coneless mouse had no rod-cone gap junctions, it was suggested that the secondary rod pathway is subserved by direct chemical synapses between rods and OFF bipolar cells (see Fig. 1C). Subsequent studies showed that rods make chemical synapses with OFF cone bipolar cells (Hack et al., 1999; Tsukamoto et al., 2001; Fyk-Kolodziej et al., 2003; Li et al., 2004). It is presently unclear whether rod-driven OFF signals use two or three distinct pathways.

Here, we show that all three rod pathways are functional but operate under widely different stimulus intensity ranges. Interestingly, we find ganglion cells for which the scotopic responses are derived from only one of the rod pathways, yet others exhibit 

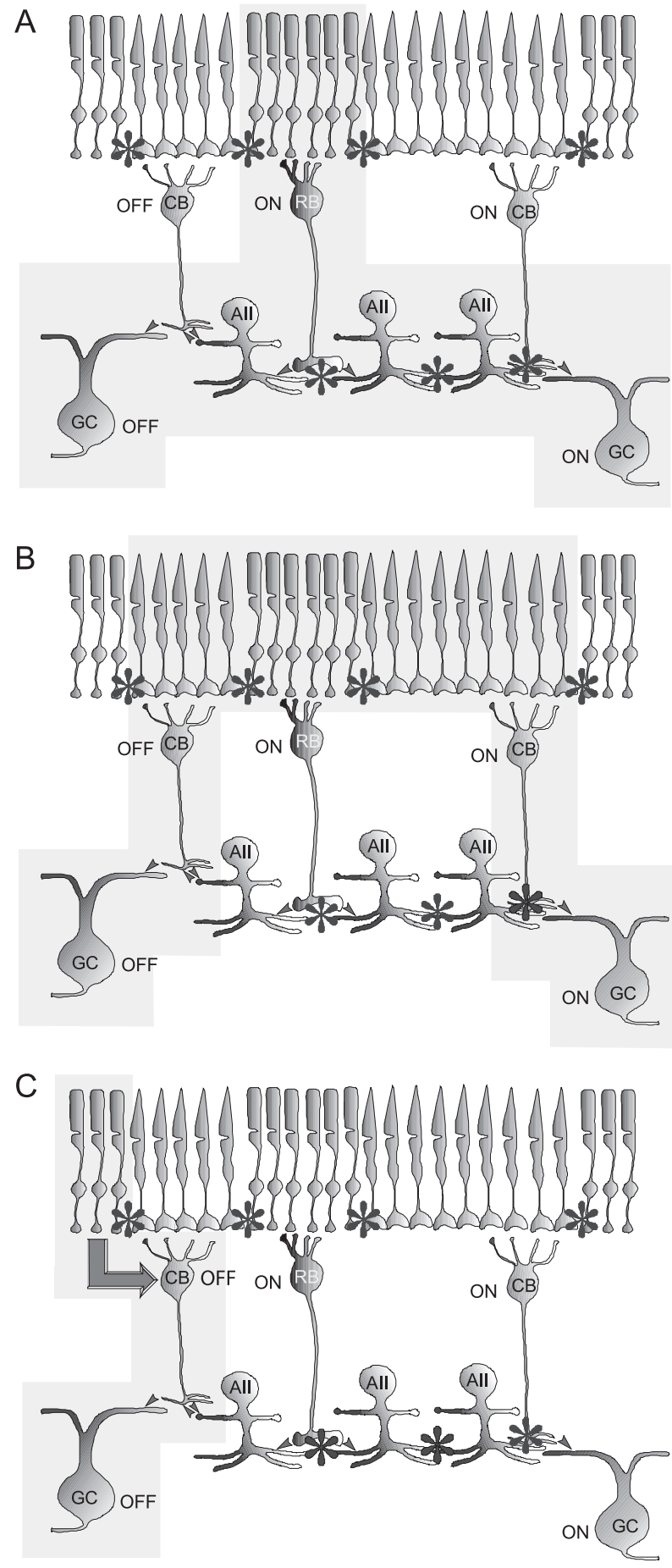

Figure 1. Multiple rod pathways in the mammalian retina. $A$, In the primary rod pathway, the rod-mediated signals are transmitted to rod bipolar cells and subsequently to All amacrine cells. All amacrine cells then make sign-conserving electrical synapses with ON cone bipolar cell axon terminals as well as sign-inverting chemical synapses with OFF cone bipolar cell axon terminals in the inner plexiform layer. In turn, the ON and OFF cone bipolar cells transmit the rod signals to ON and OFF ganglion cells, respectively. In all panels, the asterisks indicate electrical synapses, arrowheads indicate chemical synapses, and shaded areas mark the elements of the particular rod pathway. CB, Cone bipolar cell; RB, rod bipolar cell; All, All amacrine cell; $G$, ganglion cell. B, In the secondary rod pathway, the rod-mediated signals move directly from rod to cone photoreceptors via interconnecting gap junctions. Then the rod signals are relayed to $0 \mathrm{~N}$ and $\mathrm{OFF}$ cone bipolar cells, which carry the signals to ganglion cells in the inner retina. C, A tertiary rod pathway provides an additional route for rod-mediated signals to reach $0 \mathrm{FF}$ ganglion cells. In this pathway, the rod photoreceptors make direct, sign-conserving chemical synapses with a type of OFF cone bipolar cell, which, in turn, transmits rod signals to OFF ganglion cells. The large arrow indicates the direct chemical contact between rods and OFF bipolar cells. convergent signals. Our results thus indicate an unexpected complexity in the organization of scotopic signaling within the retina.

\section{Materials and Methods}

Preparation. Adult (postnatal day 42-90) wild-type and Cx36 knock-out (KO) mice (Deans et al., 2001) were used for both tracer injections and electrophysiological recordings. The mice were anesthetized deeply with an intraperitoneal injection of Nembutal ( $0.08 \mathrm{gm} / \mathrm{gm}$ body weight). Lidocaine hydrochloride $(20 \mathrm{mg} / \mathrm{ml})$ was applied locally to the eyelids and surrounding tissue. A flattened retinal-scleral preparation developed for rabbit by Hu et al. (2000) was adopted and modified for the mouse. Briefly, the eye was removed under dim red illumination and hemisected anterior to the ora serrata. Anterior optics and the vitreous humor were removed, and the resultant retina eyecup was placed in a superfusion chamber. Several radial incisions were made peripherally, allowing the eyecup to be flattened. Then the chamber was mounted in a light-tight Faraday cage and superfused with oxygenated mammalian Ringer's solution, pH 7.4 $\left(32^{\circ} \mathrm{C}\right)$ (Bloomfield and Miller, 1982).

Electrical recordings. Extracellular recordings then were obtained from ganglion cells by using insulated tungsten microelectrodes with resistances of $0.9-1.2 \mathrm{M} \Omega$ (Micro Probe, Potomac, MD). Spike trains were recorded digitally at a sampling rate of $20 \mathrm{kHz}$ with Axoscope (Axon Instruments, Foster City, CA). For additional off-line analysis, Off-line Sorter (Plexon, Dallas, TX) and Nex (Nex Technologies, Littleton, MA) software were used. Intensity-response profiles for individual cells were generated by tabulating spike counts in $500 \mathrm{msec}$ bins before, during, and after the presentation of a $500 \mathrm{msec}$ duration stimulus with intensities varied over $6 \log$ units. Numbers of light-evoked ON and OFF spikes of ganglion cells were calculated by a subtraction of the background spike activity from those evoked by the light stimulus onset and offset, respectively. Averaged response data then were normalized and plotted against the intensity of the light stimuli with Origin software (Microcal Software, Northampton, MA). Data points were fit by the classic Michaelis-Menten equation [Naka and Rushton (1966); cf. Baylor et al. (1974); Thibos and Werblin (1978)] as follows:

$$
R=\left(R_{\max } I^{\mathrm{a}}\right) /\left(I^{\mathrm{a}}+\sigma^{\mathrm{a}}\right),
$$

where $R$ indicates the measured response, $R_{\max }$ indicates the maximum response, $I$ indicates stimulus intensity, $\sigma$ indicates light intensity that produces a response of $0.5 R_{\max }$, and $a$ is the Hill coefficient. Response thresholds for individual cells were taken as $5 \%$ of maximal spike frequency.

Changes in the adaptational state of the retina will result in changes in the sensitivities of individual cells, resulting in a shift in their intensityresponse functions along the abscissa (Green et al., 1975; Dowling and Ripps, 1977). So that the intensity-response functions of different cells in different retinas could be compared, it was thus imperative to maintain all cells in this study under the same adaptational conditions. We chose to study all retinas in a well dark-adapted state. To this end, the animals were maintained overnight in complete darkness, all surgery was performed under dim red illumination, and the intact retina eyecups were placed in total darkness for $1 \mathrm{hr}$ before electrophysiological experiments. In addition, after presentation of a series of different intensity stimuli it was necessary to re-dark adapt retinas before the continuation of experimental recordings. In preliminary experiments, we found that, after presentation of a stimulus intensity series, even the most sensitive ganglion cells recovered their response thresholds after $15 \mathrm{~min}$ in complete darkness. Therefore, to be absolutely sure that retinas adapted back to their original condition, we left retinas in complete darkness for $1 \mathrm{hr}$ before subsequent recordings were made.

Light stimulation. A green $(\lambda=468 \mathrm{~nm})$ light-emitting diode delivered uniform full-field visual stimuli on the surface of the retina. The intensity of the square wave light stimuli was calibrated with a portable radiometer/photometer (Ealing Electro-Optics, Holliston, MA) and expressed in terms of the time-averaged rate of photoisomerizations per rod per second $\left(\mathrm{Rh}^{*}\right.$ per rod/sec). Light intensities were calculated assuming an average rod density of $437,000 \mathrm{rods} / \mathrm{mm}^{2}$ (Jeon et al., 1998) and quantum efficiency of 0.67 (Penn and Williams, 1984). The intensity of the 


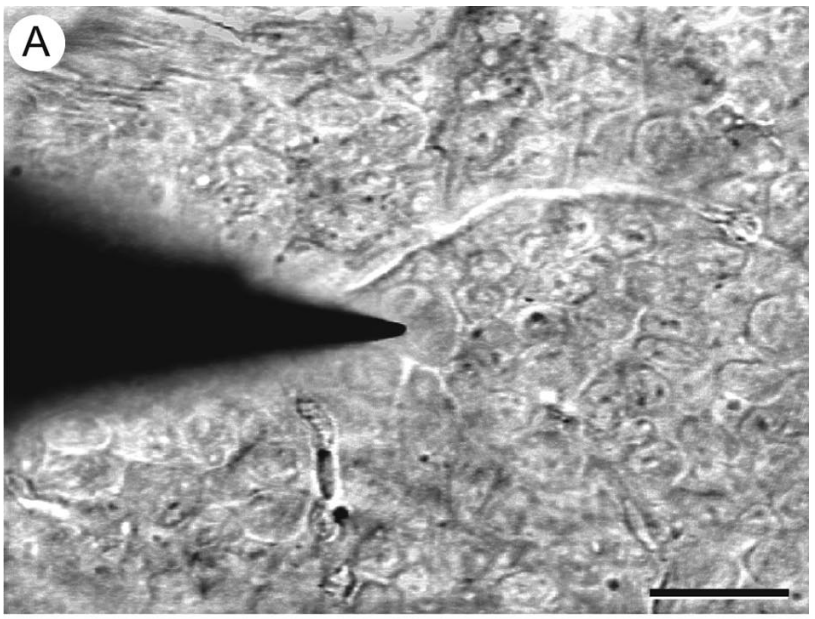

B

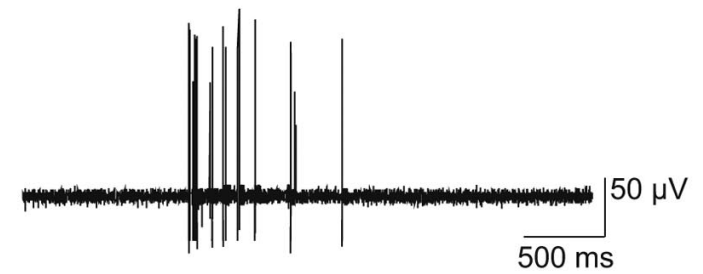

C

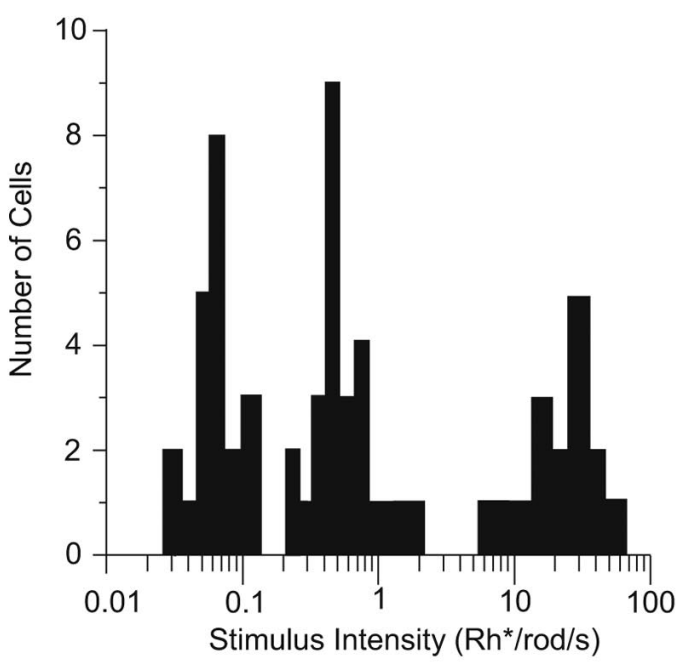

D

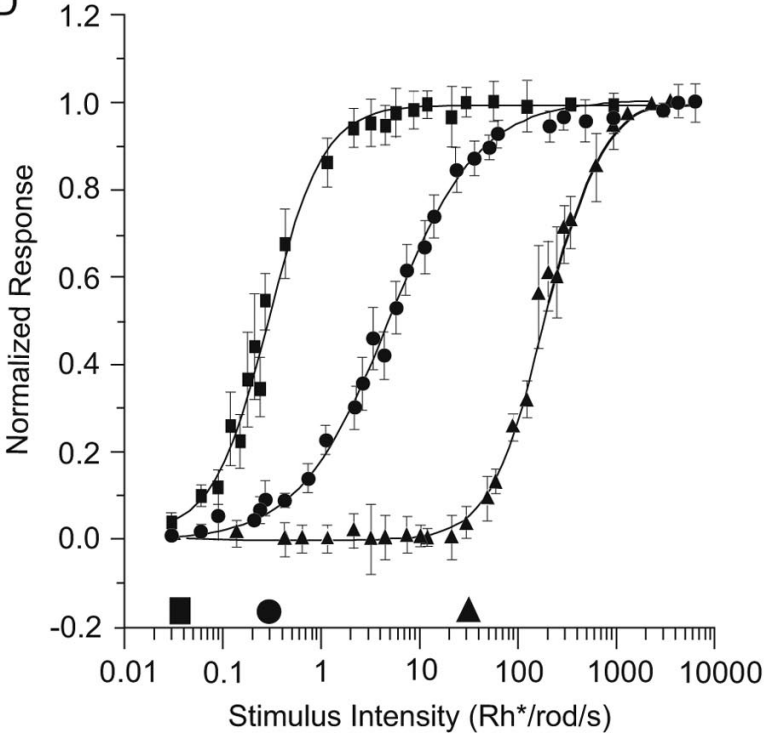

light stimuli varied from $10^{-2}$ to $10^{4} \mathrm{Rh}^{*}$ per rod/sec. For generation of intensity-response functions, the light stimuli were always presented in order of lowest to highest intensity.

Because the light stimuli were full field, it is possible that the strength of surround inhibition could vary under different stimulus intensities, thereby influencing the intensity-response data. However, there is strong evidence that ganglion cell surrounds are minimized or abolished under the dark-adapted conditions we used in this study (Rodieck and Stone, 1965; Maffei et al., 1971; Yoon, 1972; Cleland et al., 1973; Peichl and Wässle, 1983; Muller and Dacheux, 1997). In fact, we saw no evidence of surround discharges in response to the dimmest lights and usually only when we used the brightest photopic stimuli, nor did we detect a flattening of the right part of intensity-response curves corresponding to the presentation of brighter lights when surrounds should be increased in magnitude; all intensity-response curves were well fit by a single Michaelis-Menten function. Together, these data suggest that surround inhibition did not affect the response data significantly under our recording conditions.

Histology. Intracellular tracer injections of AII amacrine cells were made with standard borosilicate glass microelectrodes (Sutter Instrument, Novato, CA). Electrodes were filled at their tips with $4 \% \mathrm{~N}-(2-$ aminoethyl)-biotinamide hydrochloride (Neurobiotin, Vector Laboratories, Burlingame, CA) in $0.1 \mathrm{~m}$ Tris buffer, $\mathrm{pH} 7.6$, and then backfilled with $4 \mathrm{~m}$ potassium chloride. Neurobiotin was iontophoresed into the neurons by using a sinusoidal ( $3 \mathrm{~Hz}, 0.8 \mathrm{nA}$ peak-to-peak) current for 15 $\min$. At $1 \mathrm{hr}$ after the labeling of the last cell, the retina was fixed in a cold $\left(4^{\circ} \mathrm{C}\right)$ solution of $4 \%$ paraformaldehyde in $0.1 \mathrm{M}$ phosphate buffer, $\mathrm{pH}$ 7.3 , overnight. Retinas then were washed in phosphate buffer and soaked in a solution of $0.18 \%$ hydrogen peroxide in methyl alcohol for $1 \mathrm{hr}$. This treatment completely abolished the endogenous peroxidase activity. Retinas next were washed in phosphate buffer and reacted with the Elite ABC kit (Vector Laboratories) and 1\% Triton X-100 in sodium PBS (9\% saline, $\mathrm{pH}$ 7.6). Retinas subsequently were processed for peroxidase histochemistry by using 3,3'-diaminobenzidine (DAB). Then retinas were dehydrated and flat mounted for light microscopy.

\section{Results}

Assaying the rod pathway innervation of ganglion cells based on intensity-response profiles

An initial aim of this study was to provide a means to identify which rod pathway (or pathways) contributes the scotopic signals recorded from an individual ganglion cell. In a recent study (Deans et al., 2002), we showed that ON ganglion cells in the dark-adapted, wild-type mouse retina could be divided into distinct groups based on their response thresholds. Figure $2 C$ illustrates the frequency histogram of the response threshold of 67 ON cells in the wild-type mouse retina, clearly showing three distinct distributions. Cells thereby were sorted by response threshold into three groups within the upper and lower limits of

\section{$\leftarrow$}

Figure 2. Recordings of ganglion cells in the flattened retina eyecup preparation of the mouse. $A$, Digital video showing the surface of a live mouse retina eyecup preparation illuminated with trans-scleral infrared light. The outlines of somata in the ganglion cell layer are clearly visible. The tip of a tungsten extracellular electrode targets a ganglion cell soma in the middle of the frame. Scale bar, $50 \mu \mathrm{m}$. B, Extracellular recording of an ON ganglion cell showing an increased spike frequency in response to the onset of the light stimulus. Bottom trace represents the onset and offset of the light stimulus (light intensity $=1 \mathrm{Rh}^{*}$ per rod/sec). C, Frequency histogram showing the response thresholds of $670 \mathrm{~N}$ ganglion cells in the wild-type mouse retina. The cells are clustered into three distinct groups. D, Intensity-response profiles showing the normalized responses of $\mathrm{ON}$ ganglion cells as a function of the light intensity (adopted from Deans et al., 2002). $0 \mathrm{~N}$ ganglion cells formed four physiological groups based on their threshold responses and intensity-response profiles. Three groups with restricted operating ranges were identified as high- (squares; $n=22$ ), intermediate- (circles; $n=27$ ), and low- (triangles; $n=15$ ) sensitivity cells. The symbols along the abscissa indicate the value of threshold responses (5\% of maximum) for each group. Each data point shows the average and SE of multiple cells. 
A

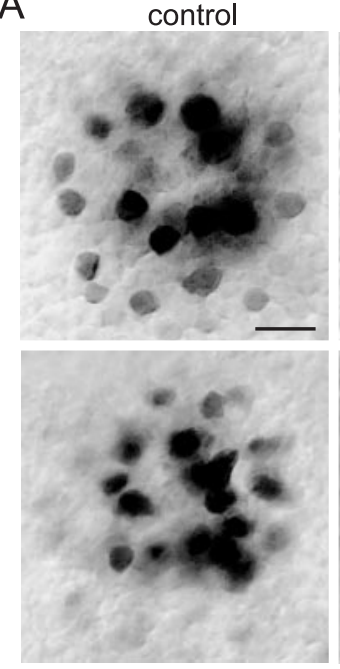

C

control

$0.04 \mathrm{Rh}^{*} / \mathrm{rod} / \mathrm{s}$

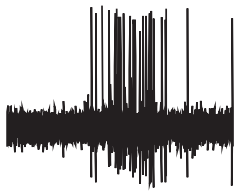

$100 \mu \mathrm{M}$ SNAP

$0.04 \mathrm{Rh}^{*} / \mathrm{rod} / \mathrm{s}$

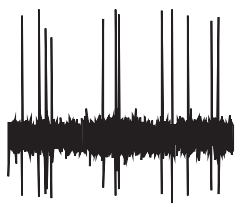

$100 \mu \mathrm{M}$ SNAP

$1 \mathrm{Rh} / \mathrm{rod} / \mathrm{s}$

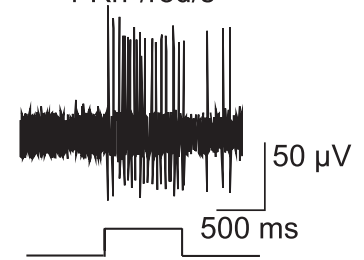

$100 \mu \mathrm{M}$ SNAP

B

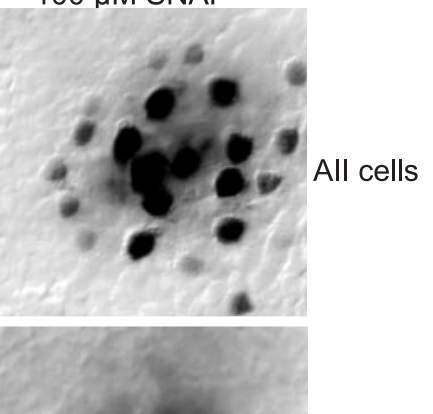

Bipolar cells

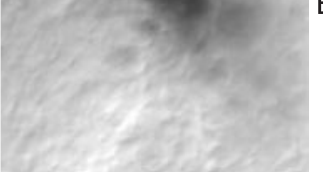

D control $0.04 \mathrm{Rh}^{*} / \mathrm{rod} / \mathrm{s}$

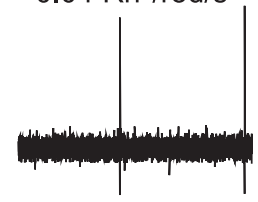

control $1 \mathrm{Rh}^{*} / \mathrm{rod} / \mathrm{s}$

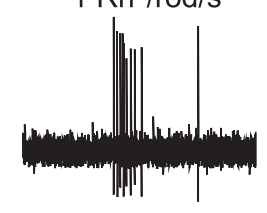

$100 \mu \mathrm{M}$ SNAP

$1 \mathrm{Rh} / \mathrm{rod} / \mathrm{s}$

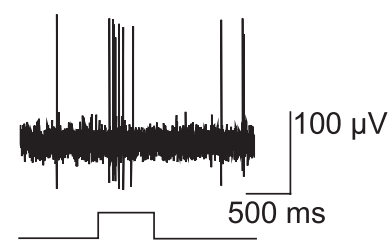

$E$

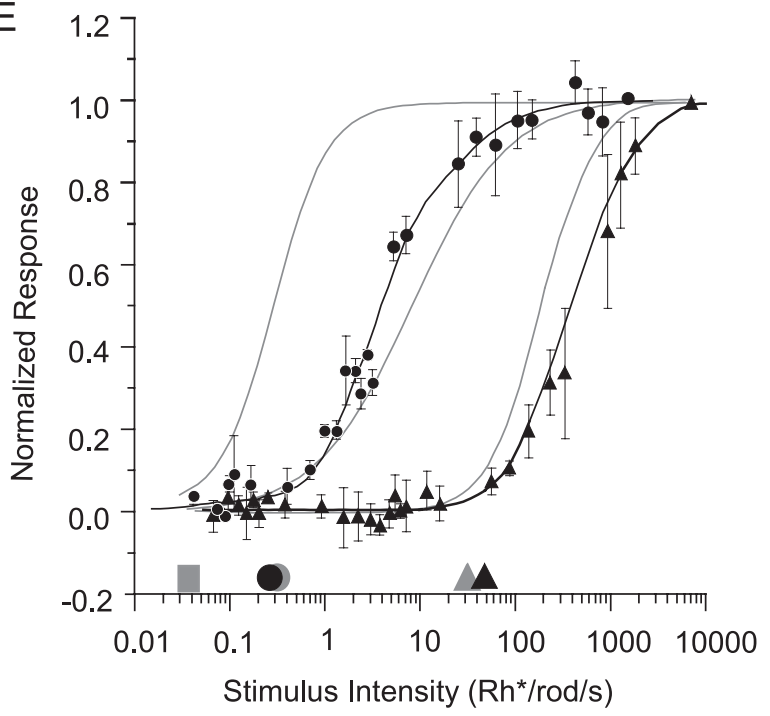

each distribution. These three groups showed restricted operating ranges for which the averaged intensity-response profiles could be fit with single Michaelis-Menten functions (Fig. 2D). Ganglion cells with the highest threshold were termed "low sensitivity" ( $n=15)$ and showed responses to light intensities above $30 \mathrm{Rh}^{\star}$ per rod/sec, which corresponded to the threshold of cone photoreceptors. Thus low-sensitivity ON ganglion cells showed pure cone-driven responses. In contrast, the other two ON ganglion cell groups, termed "high sensitivity" $(n=22)$ and "intermediate sensitivity" ( $n=27)$, responded within the scotopic intensity range, with the former displaying thresholds $\sim 1$ log unit more sensitive.

The two distinct physiological classes of scotopic ON cell responses could reflect differential input by the primary and secondary rod pathways. If so, it follows that the two rod pathways carry signals with different thresholds and operating ranges, and so the intensity-response profile of a ganglion cell could be used to identify the rod pathway providing input. So that we could test this hypothesis, our experimental strategy was to disrupt selectively one of the rod pathways and assess the effects on the different ganglion cell groups. Extracellular recordings were made in a newly designed in vitro preparation of the mouse retina eyecup in which ganglion cells were visualized by using trans-scleral illumination with infrared light. In this way, the retinas could be maintained in a dark-adapted state even while visualized cells were targeted and recorded with tungsten electrodes (Fig. $2 A, B$ ).

To suppress the primary rod pathway, we exposed wild-type mouse retinas to the nitric oxide donor, $S$-nitroso- $N$-acetylpenicillamine (SNAP), which blocks the gap junctions coupling AII amacrine cells to ON cone bipolar cells in the rabbit (Mills and Massey, 1995). The application of SNAP thus selectively should block signals carried by the primary rod pathway to ON ganglion cells. To assess directly the effects of SNAP on AII cell-cone bipolar cell coupling in mouse retina, we injected AII amacrine cells with the low-molecularweight tracer Neurobiotin, which can permeate both AII-AII cell and AII-ON cone bipolar cell gap junctions (Vaney, 1994; Mills and Massey, 1995; Bloomfield et al., 1997; Deans et al., 2002). In control mouse retinas, the injection of Neurobiotin into a single AII amacrine cell resulted in an array of tracer-coupled AII cell bodies in the

\footnotetext{
Figure 3. Pharmacological blockage of the primary rod pathway with SNAP disrupts responses of high-sensitivity $\mathrm{ON}$ cells. A, B, Flat-mount photomicrographs showing tracer coupling after intracellular injection of Neurobiotin into a single All amacrine cell in the wild-type mouse retina. Plane of focus is on the proximal INL (level of All cell somata; $A, B$, top panels) or distal INL (level of cone bipolar cell somata; $A, B$, bottom panels). Under control conditions, the tracer has permeated gap junctions to label neighboring All cells ( $A$, top panel) as well as $0 \mathrm{~N}$ cone bipolar cells ( $A$, bottom panel). However, incubation in $100 \mu \mathrm{m}$ SNAP for $1 \mathrm{hr}$ eliminated all tracer coupling to cone bipolar cells ( $B$, bottom panel) but did not disturb the coupling between neighboring All amacrine cells ( $B$, top panel). These data confirm that SNAP selectively disrupts All-cone bipolar cell gap junctions. C, Extracellular recordings from a high-sensitivity ON ganglion cell showing that responses to dim light (top trace) stimuli are abolished by the application of $100 \mu \mathrm{m}$ SNAP (middle trace). However, the cell still could be activated with relatively bright stimuli (bottom trace). D, Extracellular recordings from an intermediate sensitivity ON ganglion cell showing no light-evoked response to very dim light (top trace) but responses to brighter scotopic light (middle trace). Light-evoked responses of this cell are not affected by the application of $100 \mu \mathrm{M}$ SNAP (bottom trace). E, Comparison of the normalized intensity-response profiles and thresholds of $\mathrm{ON}$ ganglion cells in control conditions (gray curves and symbols) and those after the application of $100 \mu \mathrm{M}$ SNAP (dark curves and symbols). Conventions are the same as in Figure $2 C$. The application of SNAP eliminated the curve for high sensitivity cells but had no effect on those of intermediate- or low-sensitivity cells. Surviving curves include those for high-sensitivity cells that were shifted rightward after the application of SNAP. Cells were sorted after SNAP application by using the same threshold criteria defined in control retinas (Fig. 2O).
} 
proximal edge of the inner nuclear layer (INL) as well as a more distal network of cone bipolar cell bodies (Fig. 3A). However, preincubation of the retina with $100 \mu \mathrm{M}$ SNAP for $1 \mathrm{hr}$ prevented tracer movement into the cone bipolar cells without affecting movement between neighboring AII cells (Fig. $3 B$ ). These data illustrate that SNAP selectively uncouples AII cells from cone bipolar cells in mouse retina, thereby effectively disrupting the primary rod pathway to $\mathrm{ON}$ ganglion cells.

Application of $100 \mu \mathrm{M}$ SNAP had differential effects on highand intermediate-sensitivity ON ganglion cells. After SNAP treatment high-sensitivity $\mathrm{ON}$ ganglion cells no longer responded to threshold intensity light stimuli $\left(0.05-0.1 \mathrm{Rh}^{*}\right.$ per $\mathrm{rod} / \mathrm{sec}$ ) but remained responsive to brighter lights (Fig. $3 \mathrm{C}$ ). In contrast, SNAP had no significant effect on the responses of intermediate- or low-sensitivity $\mathrm{ON}$ cells (Fig. 3D). These data indicate that high-sensitivity $\mathrm{ON}$ cells in the dark-adapted retina receive rod input through the primary rod pathway, whereas intermediate ON cells receive scotopic signals through the secondary pathway, which is not affected by SNAP. In addition, these results indicate that cone circuitry, reflected by the activity of low sensitivity ON cells, was functioning normally during exposure to SNAP. Figure $3 E$ compares the intensity-response function of ON cells found in control retinas with those of $21 \mathrm{ON}$ cells in other retinas exposed to SNAP. The curve corresponding to the averaged intensity-response function for high-sensitivity cells is not seen in the retinas exposed to SNAP, whereas those corresponding to intermediate- and low-sensitivity cells are still present. As detailed below, SNAP produced a shift in the intensity-response curves of high-sensitivity cells, and so the surviving curves in Figure $3 E$ reflect not only unaffected intermediate- and low-sensitivity cells but the shifted curves of high-sensitivity cells as well.

\section{Convergence/segregation of the rod pathways to $\mathrm{ON}$ ganglion cells}

Our results support the aforementioned hypothesis that the scotopic threshold and intensity-response function of a darkadapted ganglion cell together form a reliable indicator of the rod pathways providing its input. Our data reveal an apparent segregation of the rod pathways whereby the primary pathway innervates high sensitivity $\mathrm{ON}$ cells and the secondary pathway innervates intermediate sensitivity cells. However, as previously mentioned, SNAP does not eliminate responses from highsensitivity ganglion cells; it shifts their thresholds and intensityresponse functions in a manner suggesting both segregation and convergence of the rod pathways.

Approximately $40 \%$ of the high sensitivity cells (5 of 12) displayed a rightward shift of their intensity-response functions to a position corresponding to that of the cone-driven, low-sensitivity cells under control conditions (Fig. $4 B$ ), indicating that these cells receive scotopic input exclusively from the primary rod pathway. In contrast, the remaining high-sensitivity cells (7 of 12) displayed a rightward shift that coincided closely with those of the dark-adapted intermediate-sensitivity cells under control conditions (Fig. 4A). These cells thus appeared to have mixed input from both the primary and secondary rod pathways. Together, these data indicate three distinct patterns of rod input to ON ganglion cells: (1) high-sensitivity cells with input exclusively from the primary rod pathway, (2) intermediate cells with rod input exclusively from the secondary rod pathway, and (3) cells with mixed rod pathway inputs. It is important to note that the different types of ganglion cell often were recorded side by side in the same retinas under identical adaptational conditions.
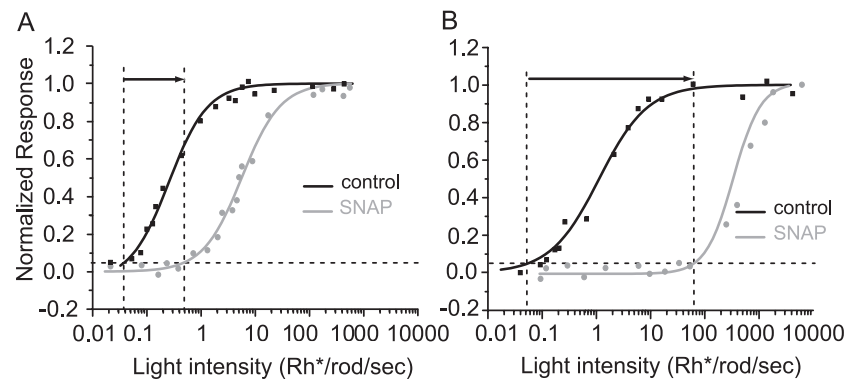

Figure 4. Convergence/segregation of the rod pathways to $0 \mathrm{~N}$ ganglion cells. $A$, Intensityresponse profile of a high sensitivity $0 \mathrm{~N}$ ganglion cell (dark curve) shifted rightward after 100 $\mu$ M SNAP application (gray curve). The threshold line (horizontal dashed line parallel to the abscissa) indicates $5 \%$ of maximum response. Vertical dashed lines mark thresholds of the cell in control conditions as well as during SNAP application. Arrow between the vertical dashed lines indicates the extent of the rightward shift of thresholds and intensity-response curves during drug application. This high sensitivity cell showed a small shift (from 0.04 to $0.5 \mathrm{Rh}^{*}$ per $\mathrm{rod} / \mathrm{sec}$ ) of the threshold response during SNAP application. The shifted curve corresponds to those of intermediate sensitivity cells in control conditions, suggesting that this cell received rod-mediated inputs through both primary and secondary rod pathways. The same effect of SNAP was detected in other ganglion cell recordings as well $(n=7)$. B, High-sensitivity cell showing a big shift of threshold responses (from 0.05 to $60 \mathrm{Rh}^{*}$ per rod/sec) after the application of $100 \mu \mathrm{M}$ SNAP. The shifted curve corresponds to those of photopic ganglion cells in control conditions, suggesting that this $0 \mathrm{~N}$ center ganglion cell received segregated rod input through the primary rod pathway. Conventions are the same as in $A$. The same effect of SNAP was detected in other ganglion cell recordings as well $(n=5)$.

\section{Intensity-response profiles of OFF ganglion cells}

We extended our analysis to determine the rod pathways innervating OFF ganglion cells. OFF cells displayed a wide range of physiological activities in terms of transient/sustained components, response thresholds, and spontaneous/light-evoked spike frequencies. Responses of two OFF ganglion cells in the wild-type mouse retina to varying stimulus intensities are illustrated in Figure $5 A$. Both OFF cells show a characteristic reduced spike activity during stimulus presentation and an increased activity at light offset, although they differ in the duration of these response components. However, the cells show a large difference in sensitivity wherein the cell responses at the left display a threshold $>10$-fold higher than those at the right $\left(0.2 \mathrm{vs} 8.3 \mathrm{Rh}^{*}\right.$ per $\mathrm{rod} / \mathrm{sec})$.

The frequency histogram of the response thresholds of $76 \mathrm{OFF}$ ganglion cells in control retinas showed four distinct distributions (Fig. 5B). Cells then were divided into four groups based on the distribution in which their threshold response fell. The averaged, normalized intensity-response profiles for cells in each group were fit with Michaelis-Menten functions (Fig. 5C). The group with the highest sensitivity $(n=16)$ showed a response threshold of $0.04 \mathrm{Rh}^{*}$ per $\mathrm{rod} / \mathrm{sec}$, with the remaining three groups ( $n=14,39$, and 4 , respectively) showing a sequential rise in threshold in $\sim 1 \log$ unit increments.

A comparison of the intensity-response profiles for the OFF ganglion cells with those for ON cells (Fig. 2C) reveals remarkable similarities. Both $\mathrm{ON}$ and OFF ganglion cells can be placed into high-, intermediate-, and low-sensitivity categories with corresponding intensity-response profiles and thresholds. The clear difference is that a subset of OFF ganglion cells forms a unique fourth group; we will refer to this group as low-intermediatesensitivity cells. Because the threshold for cone activation is $\sim 30$ $\mathrm{Rh}^{\star}$ per rod/sec (Deans et al., 2002), it is clear that low-sensitivity $\mathrm{ON}$ and OFF ganglion cells express only cone-mediated responses. Moreover, our data indicate that, whereas there are two distinct physiological groups of $\mathrm{ON}$ ganglion cells responding 
A

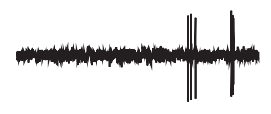

0.2

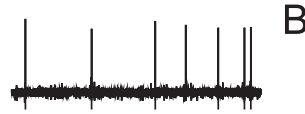

$\mathrm{Rh}^{*} / \mathrm{rod} / \mathrm{sec}$

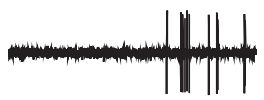

4.7
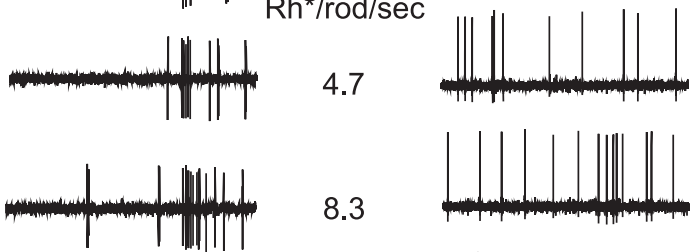

8.3
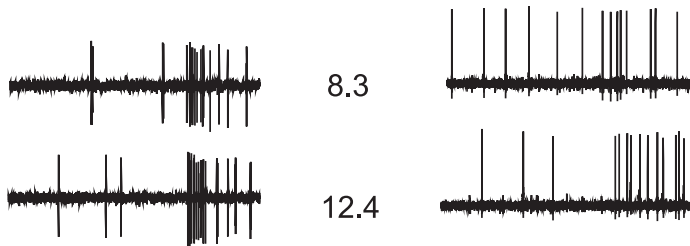

12.4
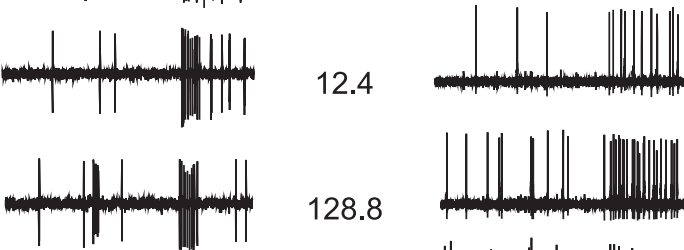

128.8
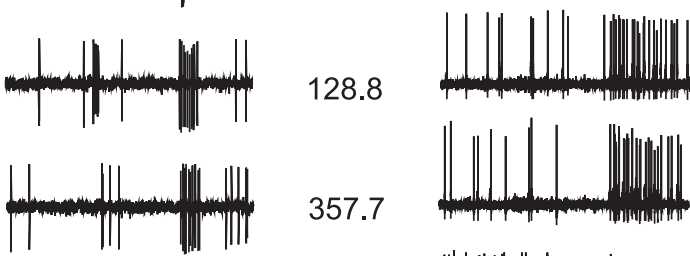

357.7
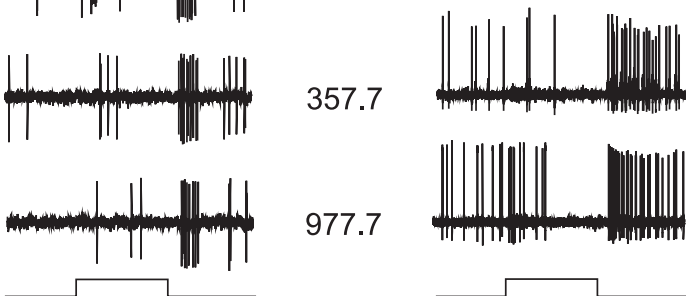

977.7

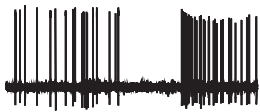

C

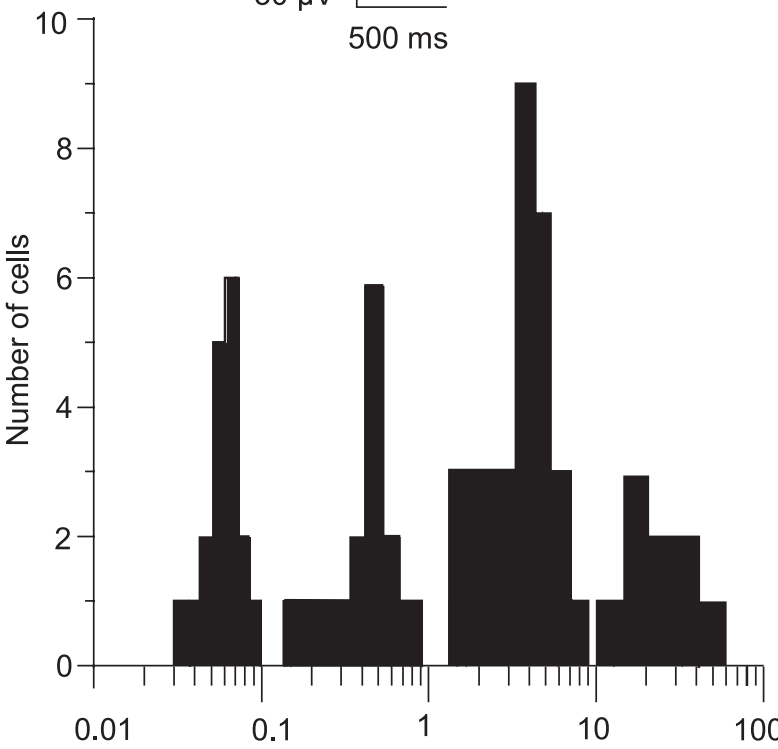

0.01

Stimulus Intensity (Rh*/rod/s)

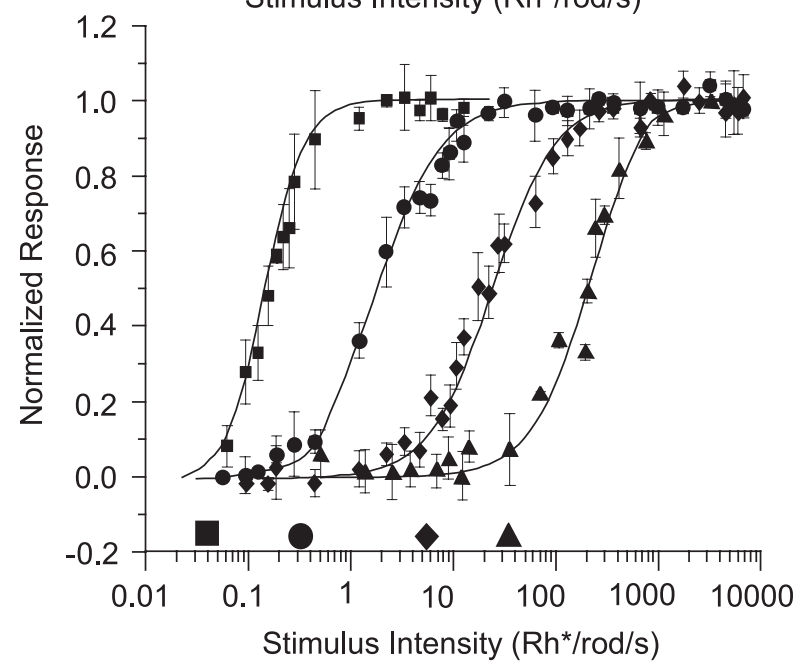

within the scotopic intensity range, there are three distinct groups of OFF cells.

It should be noted that we also found a group of OFF ganglion cells with broad operating ranges extending over 6 log units of stimulus intensity; these cells are similar to a class of ON cells reported in our previous study (Deans et al., 2002). However, ganglion cells with broad operating ranges were encountered only rarely and have been excluded from our present analyses.

\section{Identification of the rod pathways subserving the different} OFF ganglion cell groups

Disruption of the primary rod pathway with

L-2-amino-4-phosphonobutyrate

As in the case of the ON pathways, the distinct classes of OFF responses might reflect the presence of three distinct OFF rod signaling pathways (Fig. 1). To examine this possibility, we selectively disrupted one or more of the rod pathways and assessed the effects on OFF ganglion cell responses.

First we used the glutamate analog L-2-amino-4-phosphonobut-yrate (L-AP-4), which selectively activates mGluR6 receptors on rod bipolar cells as well as on-center cone bipolar cells, thereby blocking visual signals carried by the primary rod pathway (Slaughter and Miller, 1981; Massey et al., 1983; Bloomfield and Dowling, 1985a,b; Nakajima et al., 1993). The application of $50 \mu \mathrm{M} \mathrm{L}-\mathrm{AP}-4$ produced a reversible blockade of the light-evoked responses of high-sensitivity OFF ganglion cells (Fig. 6A). However, high-sensitivity OFF cells still could be activated with brighter stimulus intensities that normally produced saturating responses. In contrast, L-AP-4 had no significant effects on the responses of the other physiological groups of OFF cells. Figure $6 \mathrm{~B}$ illustrates the lack of L-AP-4 effect on the response of an intermediate-sensitivity OFF ganglion cell.

Figure $6 C$ compares the intensity-response profiles of all categories of OFF cells in control retinas with those of 29 cells in other retinas exposed to L-AP-4. Clearly, the curve corresponding to high-sensitivity cells is not seen in retinas to which L-AP-4 is applied, but there are no significant changes in the profiles of the other three cell groups. These data indicate that, under darkadapted conditions, high-sensitivity OFF ganglion cells, like their ON cell counterparts, receive rod signals mainly through the primary rod pathway.

It should noted that we also used strychnine in an attempt to disrupt the primary rod pathway to OFF cells by blocking the glycinergic synapse between AII amacrine cells and OFF cone bipolar cells. Unfortunately, strychnine invariably caused a large increase in spontaneous discharges so that it was no longer possible to differentiate light-evoked from background firing.$$
\leftarrow
$$

Figure 5. Multiple rod pathways deliver signals to OFF ganglion cells. $A, B$, Extracellular recordings of an intermediate-sensitivity $(A)$ and low-intermediate- $(B)$ sensitivity OFF ganglion cell in the wild-type mouse retina. Responses to stimuli of increasing intensity are shown as we move down each panel. The values in the middle of the panels indicate the intensity of the full-field light stimuli. Traces at the bottom indicate onset and offset of the light stimuli. C, Frequency histogram showing the response thresholds of $760 \mathrm{FF}$ ganglion cells in the wild-type mouse retina. The cells are clustered into four distinct groups. D, Averaged and normalized intensity-response profiles of the four groups of OFF ganglion cells in the wild-type mouse retina. Conventions are the same as in Figure $2 C$. The four physiological groups of OFF ganglion cells are identified as high- (squares; $n=16$ ), intermediate- (circles; $n=14$ ), lowintermediate- (diamonds; $n=39$ ), and low- (triangles; $n=4$ ) sensitivity cells. Symbols along the abscissa represent the values of threshold responses for each physiological population of OFF ganglion cell. Error bars represent SE.
} 
Disruption of the secondary rod pathway in the CX36 KO mouse

There are no known pharmacological treatments that specifically disrupt the secondary rod pathway. Therefore, we used a genetic approach to eliminate Cx36, a gap junction channel-forming protein that likely contributes to rodcone electrical coupling (Deans et al., 2002). Cx36 is expressed by AII amacrine cells, a subset of ON and OFF bipolar cells, and cone photoreceptors (Deans et al., 2002; Lee et al., 2003; Feigenspan et al., 2004; Zhang and $\mathrm{Wu}, 2004)$. In Cx36 KO retinas, coupling between AII amacrine cells and between AII amacrine and cone ON bipolar cells is lost (Deans et al., 2002). Although rod-cone coupling was not tested directly, all rod ON signaling was eliminated in the $\mathrm{Cx} 36 \mathrm{KO}$, suggesting that rod-cone gap junctions were disrupted as well. Together, these data suggest that $\mathrm{Cx} 36$ is a critical component of the primary and secondary pathways to ON cells and the secondary rod pathway to OFF cells.

To study further the rod pathways innervating OFF ganglion cells, we generated intensity-response profiles of OFF cells in the Cx36 KO mouse retina. Similar to the results with L-AP- 4 in the wild-type mouse retina, we found that the intensity-response curve corresponding to highsensitivity cells was abolished, whereas the remaining three curves appeared to be unaffected in the knock-out animal (Fig. $7 A$ ). These results were surprising for two reasons. First, because the primary pathway to OFF cells should not be disrupted in the $\mathrm{KO}$, we expected that high-sensitivity cells would survive. Second, the survival of the intermediate-sensitivity OFF cell profile is in apparent conflict with our earlier finding showing that the profile for intermediate-sensitivity ON cells is lost in the Cx36 KO mouse (Deans et al., 2002). If loss of intermediate-sensitivity ON responses reflects the disruption of the secondary rod pathway by elimination of rod-cone gap junctions, then the responses of both $\mathrm{ON}$ and OFF intermediate-sensitivity cells should be lost in the $\mathrm{Cx} 36 \mathrm{KO}$. We attempted to resolve these apparent conflicts by using a pharmacological test. If the surviving OFF cells showing apparent intermediate sensitivity in the $\mathrm{KO}$ mouse were innervated by the secondary rod pathway, then they should not be affected by L-AP-4, which we showed above affects only the primary rod pathway and high-sensitivity cells. However, the application of L-AP-4 reversibly blocked the responses of the apparent intermediate-sensitivity OFF cells in the Cx36 KO (Fig. 7B). Figure 7C compares the normalized intensity-response profiles of 17 cells after exposure to L-AP-4 with those found under control conditions in the $\mathrm{Cx} 36 \mathrm{KO}$ mouse retina. Clearly, responses corresponding to intermediatesensitivity cells are eliminated by drug treatment, whereas lowintermediate- and low-sensitivity responses persist. These observations suggest that the apparent intermediate-sensitivity OFF cells receive input from the primary rod pathway. The most parsimonious explanation is that these cells correspond to highsensitivity cells in control retinas but with reduced sensitivity, possibly because of the loss of AII-AII coupling in the Cx36 KO

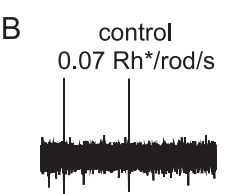

C

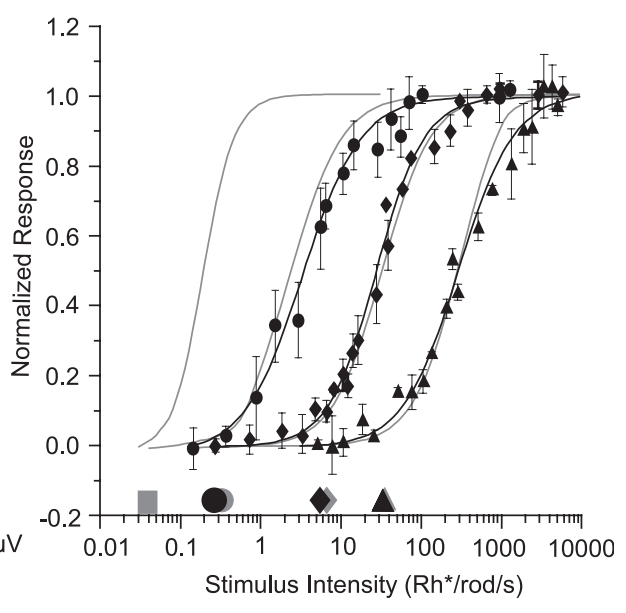

Figure 6. Pharmacological blockade of the primary rod pathway with L-AP-4 disrupts responses of high-sensitivity OFF cells. $A$, Extracellular recordings from a high-sensitivity OFF ganglion cell showing that responses to extremely dim light stimuli (top trace) (the light-evoked response of this intermediate sensitivity cell (third trace). $C_{\text {, }}$ the curve for high-sensitivity cells but had no effect on those of intermediate- $(n=13)$ ow-intermediate- $(n=10)$, or low- $(n=6)$ sensitivity cells. Surviving curves include those for high-sensitivity cells that were shifted rightward after the application of L-AP-4. Error bars represent SE.

(Deans et al., 2002) (see Discussion). If so, then the rod-mediated responses of intermediate cells are eliminated in the Cx36 KO mouse as predicted.

The response of low-intermediate-sensitivity OFF cells both is insensitive to L-AP-4 application and survives in the Cx36 KO mouse retina, suggesting that it is not subserved by either the primary or secondary rod pathways. A reasonable hypothesis is that these responses reflect the presence of a tertiary pathway, possibly corresponding to synaptic interactions between rods and cone OFF bipolar cells (Fig. 1C). Together, these data indicate that, under dark-adapted conditions, (1) the scotopic responses of high-sensitivity OFF cells are transmitted mainly by the primary rod pathway; (2) the responses of intermediate cells are derived from the secondary rod pathway; and (3) the responses of low-intermediate cells are carried by the tertiary pathway.

\section{Convergence/segregation of the signals carried by the rod pathways to OFF ganglion cells}

OFF ganglion cells in wild-type retinas displayed characteristic patterns of segregated and convergent inputs. L-AP-4 abolished the responses of high-sensitivity cells to normal stimulus intensities, but they still could be activated with brighter lights. Approximately $41 \%$ (9 of 22) of the high-sensitivity OFF cells showed a rightward shift of the intensity-response function after L-AP-4 application to a position corresponding to that of the intermediate cells (Fig. $8 \mathrm{~A}$ ). An equal number of high-sensitivity cells showed a drug-induced shift to the profile of lowintermediate cells (9 of 22) (Fig. $8 B$ ). The remaining highsensitivity cells ( 4 of 22 ) showed a shift after L-AP-4 application to a position coinciding with the intensity-response profile of the cone-driven responses (Fig. $8 \mathrm{C}$ ). Together, these data suggest at least three patterns of rod input to OFF ganglion cells: (1) cells 


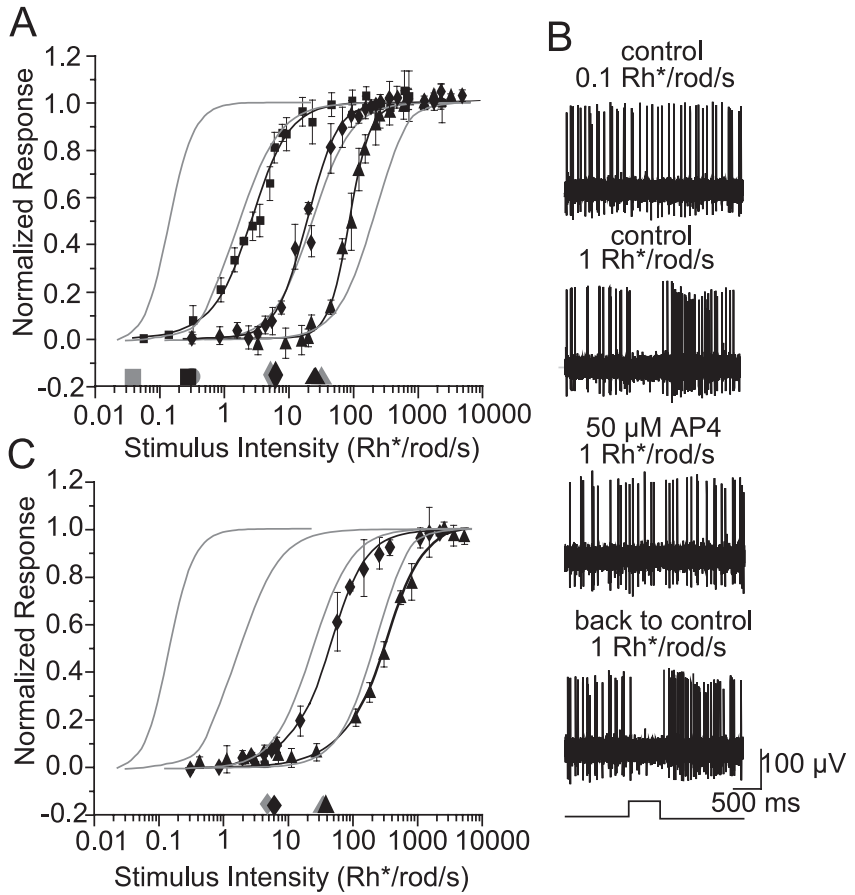

Figure 7. Intensity-response profiles of 34 OFF ganglion cells in the $\mathrm{Cx} 36$ knock-out mouse retina. $A$, Comparison of the normalized intensity-response profiles and thresholds of OFF ganglion cells in wild-type (gray curves and symbols) and (x36 knock-out mouse (dark curves and symbols) retinas. Conventions are the same as in Figure $2 C$. The curve for high-sensitivity cells is missing in the Cx36 knock-out retina, whereas the curves for the other three groups appear to be unaffected. $B$, Extracellular recordings from an apparent intermediate sensitivity OFF ganglion cell in the Cx36 knock-out retina. The application of $50 \mu \mathrm{m} \mathrm{L-AP-4}$ reversibly blocked the light-evoked response of this cell. These data indicate that the apparent intermediate-sensitivity cell is innervated mainly by the primary rod pathway. C, Comparison of the normalized intensity-response profiles and thresholds of OFF ganglion cells in the Cx36 knock-out mouse retina under control conditions (gray curves and symbols) and after the application of $50 \mu \mathrm{m} \mathrm{L-AP}-4$ (dark curves and symbols). Conventions are the same as in Figure $2 \mathrm{C}$. The application of L-AP-4 eliminated the curve for the apparent intermediate-sensitivity cells but has no effect on those of low-intermediate- $(n=6)$ or low- $(n=11)$ sensitivity cells. Error bars in $A$ and $C$ represent SE.

with convergent rod signals from primary and secondary rod pathways, (2) cells with convergent rod signals from primary and tertiary rod pathways, and (3) cells with input exclusively from the primary rod pathway.

It remains unclear from these data whether a single OFF ganglion cell can receive input from all three rod pathways. However, we can examine this question indirectly by comparing the shifts of the intensity-response functions of high-sensitivity cells in the wild-type and Cx36 KO mouse retinas exposed to L-AP-4. Under these conditions, the primary rod pathway is blocked in the wildtype mouse retina, whereas both the primary and secondary pathways are blocked in the KO. Therefore, cells with input from all three pathways should be revealed by a greater number of curves that shift to the low-intermediate cell position in the $\mathrm{KO}$ retina than in the wild type. However, we found a large increase in the rightward shift of curves to a position corresponding to that of the cone-driven low-sensitivity cells ( 8 of 11), with only a few (3 of 11) shifting to the position of low-intermediate cells (Fig. 9). This relatively large number of cells that display an intensityresponse shift to the low-sensitivity position in the L-AP-4exposed KO retinas (Fig. 9C) likely reflects a combination of cells with solely primary and mixed primary and secondary rod pathway inputs, both of which shift to photopic levels because of the disruption of both pathways. Thus, these results argue against convergence of all three rod pathways to individual OFF ganglion cells.

\section{Discussion}

\section{Multiple rod pathways display different sensitivities}

Converging evidence suggests that multiple circuits underlie the propagation of rod signals across the mammalian retina (for review, see Bloomfield and Dacheux, 2001). Applying a previous strategy (Deans et al., 2002), we used the thresholds and intensity-response profiles of ganglion cells to identify the pathway (or pathways) from which their rod signals were derived. Based on these profiles, ganglion cells were divided into multiple groups with discrete operating ranges in the dark-adapted retina: three for ON cells and four for OFF cells. ON and OFF ganglion cells designated as low sensitivity showed responses above cone threshold, indicating pure cone innervation. In contrast, high-, intermediate-, and low-intermediate-sensitivity ganglion cells operated mainly in the scotopic intensity range. The application of L-AP-4, which blocked transmission across the rod-to-rod bipolar cell synapse, eliminated high-sensitivity responses of OFF ganglion cells. Likewise, application of the NO donor, SNAP, which disrupted the AII-cone bipolar cell gap junctions, abolished the high-sensitivity responses of ON ganglion cells. Together, these data indicate that the primary rod pathway carries the dominant rod signals to high-sensitivity $\mathrm{ON}$ and OFF cells in dark-adapted retinas.

In contrast, intermediate-sensitivity $\mathrm{ON}$ and $\mathrm{OFF}$ ganglion cells in wild-type retinas were unaffected by SNAP or L-AP-4, indicating that they are not innervated by the primary rod pathway. We reported previously that responses of intermediatesensitivity ON cells were lost in the Cx36 KO retina (Deans et al., 2002), and the present data indicate that intermediate-sensitivity OFF cells are also lost (see below). Cx36 has been detected in gap junctions interconnecting rod and cone axon terminals (Deans et al., 2002; Lee et al., 2003; Feigenspan et al., 2004). Therefore, loss of intermediate-sensitivity responses in the Cx36 KO likely results from the loss of rod-cone gap junctions and disruption of the secondary rod pathway.

Overall, these data indicate a symmetrical organization of the primary and secondary rod pathways in the ON and OFF systems of the retina whereby they carry the dominant rod inputs to highand intermediate-sensitivity cells, respectively, in dark-adapted retinas. However, we discovered a fourth group of OFF ganglion cells, which responded within the scotopic range but with a lower sensitivity than high- and intermediate-sensitivity cells. These low-intermediate-sensitivity cells had no counterparts in the ON system but formed a sizable fraction of the OFF ganglion cells in this study. These cells were unaffected by the application of L-AP-4 and survived in the Cx36 KO mouse retina, indicating that they are not innervated significantly by either the primary or secondary rod pathways. These cells then must receive rod signals via the remaining tertiary rod pathway. Thus three distinct pathways subserve the transmission of rod-mediated OFF signals across the retina.

Our finding of ganglion cell responses over a broad range of stimulus intensities is consistent with earlier reports of mouse ganglion cell thresholds covering $>4$ log units (Balkema and Pinto, 1982; Stone and Pinto, 1993). The division of ganglion cells into discrete categories based on their intensity-response profiles indicates that the three rod pathways operate over widely different operating ranges. Although the significance of this organization to retinal processing is unclear, psychophysical data provide hints to their distinct functional roles. Critical flicker 
fusion frequency and threshold versus intensity functions of normal and rod monochromat subjects show a discontinuity that is thought to reflect two stages of operation (for review, see Sharpe and Stockman, 1999). These data indicate the presence of two rod pathways that underlie a transfer of either slow, low-threshold rod signals or faster ones activated at higher light intensities. Our data support the idea that the primary rod pathway mediates the slow, low-threshold signaling, whereas the faster, high-threshold signals come through the secondary pathway. The reason for an additional rod circuit in the OFF system with relatively low sensitivity is unclear. However, Tsukamoto et al. (2001) speculated that scotopic signals carried by this pathway are generated when the number of photoisomerizations is relatively high, consistent with the present findings, and dark objects moving through the visual field are backlit. Thus the tertiary rod pathway could be optimized to detect predators during the dusk or dawn.

\section{AII-AII cell coupling maintains high sensitivity of primary rod pathway}

Together with our earlier results (Deans et al., 2002), the present data show unequivocally that $\mathrm{Cx} 36$ contributes to obligatory electrical synapses in the primary and secondary rod pathways for transmission of both ON and OFF rod signals across the retina. The function of the gap junctions between AII amacrine cells is less apparent from the circuit morphology. In the Cx36 KO mouse retina, we found apparent intermediate sensitivity OFF cells. However, the finding that L-AP-4 abolished the responses of these apparent intermediate cells indicates that they are innervated mainly by the primary and not the secondary rod pathway. Thus, the apparent intermediate cells are, in fact, high-sensitivity cells for which the intensity-response profiles have been shifted rightward, whereby their response thresholds were reduced by $1 \log$ unit.

The computational study of Smith and Vardi (1995) speculated that AII cell coupling serves to sum synchronous signals and subtract asynchronous noise, thereby preserving the high fidelity of signals carried by the primary rod pathway. Additionally, plastic changes in AII cell coupling with light are thought to optimize the summing of synchronous activity across the scotopic range (Bloomfield et al., 1997). Therefore, the reduced sensitivity of high-sensitivity cells in the knock-out retina likely results from disruption of AII-AII cell coupling and the resultant reduced signal-to-noise and fidelity of AII cells signals transmitted to OFF ganglion cells. In essence, without this coupling, the primary and secondary pathways show equivalent sensitivities. These findings are thus consistent with the idea that AII-AII cell coupling is

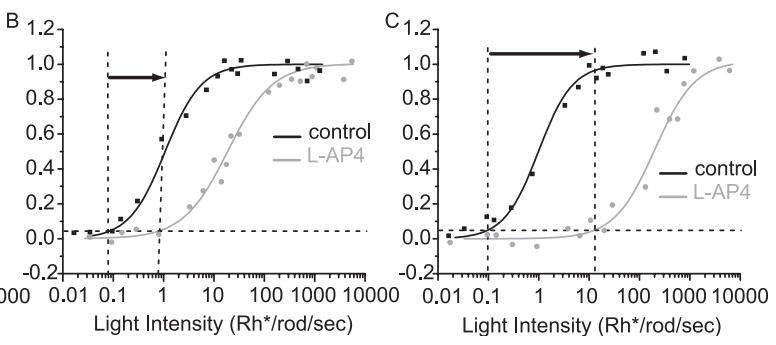

Figure 8. Convergence/segregation of the rod pathways to OFF ganglion cells in the control mouse retina. $A$, Intensityresponse profile of a high-sensitivity OFF ganglion cell (dark curve) shifted rightward after $50 \mu \mathrm{m} \mathrm{L-AP-4}$ application (gray curve). Conventions are the same as in Figure $4 A$. This high-sensitivity cell showed a small shift (from 0.05 to $0.3 \mathrm{Rh}$ * per rod/sec) of the 作 ganglion cell received convergent rod input through the primary and tertiary rod pathways. The same effect of L-AP- 4 was detected in other ganglion cell recordings as well $(n=9)$. C, High-sensitivity cell showing a big shift of threshold responses (from 0.09 to 14 $\mathrm{Rh}^{*}$ per rod/sec) after the application of $50 \mu \mathrm{m} \mathrm{L}-\mathrm{AP}-4$. Conventions are the same as in Figure $4 \mathrm{~A}$. The shifted curve corresponds to those of photopic ganglion cells in control conditions, suggesting that this OFF center ganglion cell received segregated rod input through the primary rod pathway. The same effect of L-AP-4 was detected in other ganglion cell recordings as well $(n=4)$.
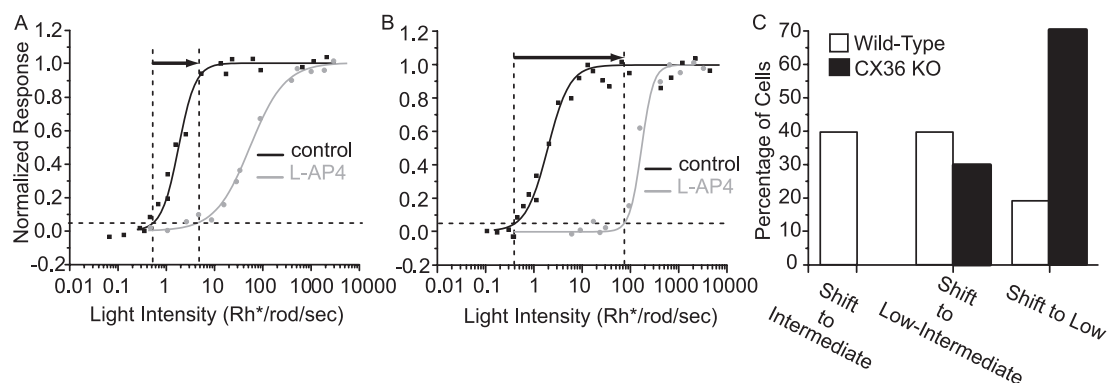

Figure 9. Convergence/segregation of the rod pathways to OFF ganglion cells in the $(x 36$ knock-out mouse retina. $A$, Intensity-response profile of an apparent intermediate sensitivity OFF ganglion cell (dark curve) shifted rightward after $50 \mu \mathrm{M} \mathrm{L-AP-4}$ threshold response during L-AP-4 application. The shifted curve corresponds to those of low-intermediate-sensitivity cells in control conditions, suggesting that this cell received rod-mediated inputs through both primary and tertiary rod pathways. The showing a shift of threshold responses (from 0.4 to $75 \mathrm{Rh}^{*}$ per rod/sec) after the application of $50 \mu \mathrm{m} \mathrm{L}-\mathrm{AP}-4$. Conventions are the same as in Figure $4 A$. The shifted curve corresponds to those of low-sensitivity ganglion cells in control conditions, suggesting that detected in other ganglion cell recordings as well $(n=8)$. C, Graph showing the frequency of rightward shifts in wild-type mice open bars) versus Cx36 knock-out animals (filled bars) after $50 \mu \mathrm{m} \mathrm{L-AP-4}$ application. In the control retina, L-AP-4 induced shift whereas a smaller population of ganglion cells showed large shifts to photopic levels ( 20\%). In the Cx36 knock-out retinas the fraction of high sensitivity cells showing intensity-response shifts to the position of low-intermediate cells was comparable to that of the control animals, whereas incidents of large shifts to photopic levels increased more than threefold.

necessary for maintenance of high-sensitivity signaling through the primary rod pathway.

\section{Convergence of the multiple rod pathways}

An unresolved question is whether the multiple rod pathways converge onto single ganglion cells. In rabbit, DeVries and Baylor (1995) reported that innervation was mostly segregated, with the primary rod pathway supplying brisk ganglion cells and the secondary pathway innervating sluggish and on-off directionselective cells. In contrast, Soucy et al. (1998) reported that most OFF ganglion cells in the mouse display both L-AP-4-sensitive and L-AP-4-insensitive rod responses, suggesting convergent inputs. Our finding of ganglion cells with discrete intensity-response profiles provides clear evidence for segregated signaling of the rod pathways, but we routinely observed evidence for conver- 
gent inputs to single ganglion cells as well. For example, the application of L-AP-4 or SNAP to block the primary rod pathway caused a rightward shift of the intensity-response profiles of high-sensitivity cells to a position matching that of either conedriven low-sensitivity or intermediate-sensitivity cells. The results, which occurred in approximately equal numbers, reflect cells with rod inputs from only the primary rod pathway or mixed primary/secondary rod pathway signals. Similarly, we found that an OFF ganglion cell can receive rod input exclusively from the primary, secondary, or tertiary rod pathways. However, the mixing of these pathways to OFF cells also occurs. Interestingly, we found evidence for mixed primary/secondary and primary/tertiary pathway input to OFF ganglion cells, yet our data suggest that all three pathways do not converge onto single OFF cells.

Our finding that some ganglion cells receive segregated inputs from the rod pathways has strong implications concerning scotopic retinal circuitry. For example, the existence of ganglion cells without inputs from the primary rod pathway suggests that not all subtypes of bipolar cells form electrical or chemical synapses with the AII amacrine cells. This idea is supported by anatomical studies in both cat and mouse retinas showing that not all ON or OFF bipolar cell types make synaptic contacts with AII cells (Cohen and Sterling, 1990; Tsukamoto et al., 2001). However, a recent study suggests that all ON bipolar cell types in rat form electrical synapses with AII cells (Veruki and Hartveit, 2002). Likewise, the finding that not all cells receive inputs via the secondary rod pathway suggests a selectivity in rod-cone coupling whereby not all cone bipolar cells carry rod signals. However, there is currently no morphological or physiological evidence for such selectivity (Raviola and Gilula, 1973; Schneeweis and Schnapf, 1995). Another explanation for the apparent segregation of inputs is suggested by the recent work of Pang and colleagues (2003). They found that certain subtypes of $\alpha$ ganglion cells appeared to show a low scotopic sensitivity based on lightevoked spiking. However, these cells showed subthreshold synaptic responses with high sensitivity, but they were not translated into a spike code, possibly because of inhibitory inputs. Thus, our findings, based on spike activity suggesting segregated inputs to ganglion cells, may indicate the predominance of the rod signaling from a particular pathway and not necessarily selective synaptic innervation. In any event, our results indicate that rod signals are segregated functionally or combined, dependent on ganglion cell type. This indicates a complex organization by which these signals are propagated not only within the retina but also by their transmission to central visual areas.

\section{References}

Balkema GW, Pinto LH (1982) Electrophysiology of retinal ganglion cells in the mouse: a study of a normally pigmented and a congenic hypopigmentation mutant, pearl. J Neurophysiol 48:968-980.

Baylor DA, Hodgkin AL, Lamb TD (1974) Reconstruction of the electrical responses of turtle cones to flashes and steps of light. J Physiol (Lond) 242:759-791.

Blakemore CB, Rushton WA (1965a) Dark adaptation and increment threshold in a rod monochromat. J Physiol (Lond) 181:612-628.

Blakemore CB, Rushton WA (1965b) The rod increment threshold during dark adaptation in normal and rod monochromat. J Physiol (Lond) 181:629-640.

Bloomfield SA, Dacheux RF (2001) Rod vision: pathways and processing in the mammalian retina. Prog Retin Eye Res 20:351-384.

Bloomfield SA, Dowling JE (1985a) Roles of aspartate and glutamate in synaptic transmission in rabbit retina. I. Outer plexiform layer. J Neurophysiol 53:699-713.

Bloomfield SA, Dowling JE (1985b) Roles of aspartate and glutamate in synaptic transmission in rabbit retina. II. Inner plexiform layer. J Neurophysiol 53:714-725.
Bloomfield SA, Miller RF (1982) A physiological and morphological study of the horizontal cell types in the rabbit retina. J Comp Neurol 208:288-303

Bloomfield SS, Xin D, Osborne T (1997) Light-induced modulation of coupling between AII amacrine cells in the rabbit retina. Vis Neurosci 14:565-576.

Boycott BB, Dowling JE (1969) Organization of the primate retina: light microscopy. Philos Trans R Soc Lond B Biol Sci 255:109-184.

Boycott BB, Kolb H (1973) The connections between bipolar cells and photoreceptors in the retina of the domestic cat. J Comp Neurol 148:115-140.

Boycott BB, Wässle H (1991) Morphological classification of bipolar cells in the macaque retina. Eur J Neurosci 3:1069-1088.

Cleland BG, Levick WR, Sanderson KJ (1973) Properties of sustained and transient ganglion cells in the cat retina. J Physiol (Lond) 228:649-680.

Cohen E, Sterling P (1990) Demonstration of cell types among cone bipolar neurons of cat retina. Philos Trans R Soc Lond B Biol Sci 330:305-321.

Connor JD (1982) The temporal properties of rod vision. J Physiol (Lond) 332:139-155.

Dacheux RF, Raviola E (1982) Horizontal cells in the retina of the rabbit. J Neurosci 2:1486-1489.

Dacheux RF, Raviola E (1986) The rod pathway in the rabbit retina: a depolarizing bipolar and amacrine cell. J Neurosci 6:331-345.

Deans MR, Gibson JR, Sellitto C, Connors BW, Paul DL (2001) Synchronous activity of inhibitory networks in neocortex requires electrical synapses containing connexin36. Neuron 31:477-485.

Deans MR, Völgyi B, Goodenough DA, Bloomfield SA, Paul DL (2002) Connexin 36 is essential for transmission of rod-mediated visual signals in the mammalian retina. Neuron 36:1-20.

DeVries SH, Baylor DA (1995) An alternative pathway for signal flow from rod photoreceptors to ganglion cells in mammalian retina. Proc Natl Acad Sci USA 92:10658-10662.

Dowling JE, Ripps H (1977) The proximal negative response and visual adaptation in the skate retina. J Gen Physiol 69:57-74.

Euler T, Wässle H (1995) Immunocytochemical identification of cone bipolar cells in the rat retina. J Comp Neurol 361:461-478.

Famiglietti EV, Kolb H (1975) A bistratified amacrine cell and synaptic circuitry in the inner plexiform layer of the retina. Brain Res 84:293-300.

Feigenspan A, Janssen-Bienhold U, Hormuzdi S, Monyer H, Degen J, Sohl G, Willecke K, Ammermuller J, Weiler R (2004) Expression of connexin36 in cone pedicles and OFF-cone bipolar cells of the mouse retina. J Neurosci 24:3325-3334.

Fyk-Kolodziej B, Qin P, Pourcho RG (2003) Identification of a cone bipolar cell in cat retina which has input from both rod and cone photoreceptors. J Comp Neurol 464:104-113.

Ghosh KK, Bujan S, Haverkamp S, Feigenspan A, Wässle H (2004) Types of bipolar cells in the mouse retina. J Comp Neurol 469:70-82.

Green DG, Dowling JE, Siegel IM, Ripps H (1975) Retinal mechanisms of visual adaptation in the skate. J Gen Physiol 65:483-502.

Hack I, Peichl L, Brandstatter JH (1999) An alternative pathway for rod signals in the rodent retina: rod photoreceptors, cone bipolar cells, and the localization of glutamate receptors. Proc Natl Sci Acad USA 96:14130-14135.

Hu EH, Dacheux RF, Bloomfield SA (2000) A flattened retina-eyecup preparation suitable for electrophysiological studies of neurons visualized with trans-scleral infrared illumination. J Neurosci Methods 103:209-216.

Jeon CJ, Srettoi E, Masland RH (1998) The major cell populations of the mouse retina. J Neurosci 18:8936-8946.

Lee EJ, Han JW, Kim HJ, Kim IB, Lee MY, Oh SJ, Chung JW, Chun MH (2003) The immunocytochemical localization of connexin36 at rod and cone gap junctions in the guinea pig retina. Eur J Neurosci 18:2925-2934.

Li W, Keung JW, Massey SC (2004) Direct synaptic connections between rods and OFF cone bipolar cells in the rabbit retina. J Comp Neurol 474:1-12.

Maffei L, Fiorentini A, Cervetto L (1971) Homeostasis in retinal receptive fields. J Neurophysiol 34:579-587.

Massey SC, Redburn DA, Crawford ML (1983) The effects of 2-amino-4phosphonobutyric acid (APB) on the ERG and ganglion cell discharge of rabbit retina. Vision Res 23:1607-1613.

Mills SL, Massey SC (1995) Differential properties of two gap junctional pathways made by AII amacrine cells. Nature 377:734-737. 
Müller F, Wässle H, Voigt T (1988) Pharmacological modulation of the rod pathway in the cat retina. J Neurophysiol 59:1657-1671.

Muller JF, Dacheux RF (1997) Alpha ganglion cells of the rabbit retina lose antagonistic surround responses under dark adaptation. Vis Neurosci 14:395-401.

Naka KI, Rushton WA (1966) An attempt to analyse colour reception by electrophysiology. J Physiol (Lond) 185:556-586.

Nakajima Y, Iwakabe H, Akazawa C, Nawa H, Shigemoto R, Mizuno N, Nakanishi S (1993) Molecular characterization of a novel metabotropic glutamate receptor mGLUR6 with a high selectivity for L-2-amino-4phosphono butyrate. J Biol Chem 286:11863-11873.

Nelson R (1977) Cat cones have rod input: a comparison of response properties of cones and horizontal cell bodies in the retina of the cat. J Comp Neurol 172:109-136.

Pang JJ, Gao F, Wu SM (2003) Light-evoked excitatory and inhibitory synaptic inputs to ON and OFF $\alpha$ ganglion cells in the mouse retina. J Neurosci 23:6063-6073.

Peichl L, Wässle H (1983) The structural correlate of the receptive field centre of alpha ganglion cells in the cat retina. J Physiol (Lond) 341:309-324.

Penn JS, Williams TP (1984) A new microspectrophotometric method for measuring absorbance of rat photoreceptors. Vision Res 24:1673-1676.

Pignatelli V, Strettoi E (2004) Bipolar cells of the mouse retina: a gene gun, morphological study. J Comp Neurol 476:254-266.

Raviola E, Gilula NB (1973) Gap junctions between photoreceptor cells in the vertebrate retina. Proc Natl Acad Sci USA 70:1677-1681.

Rodieck RW, Stone J (1965) Analysis of receptive fields of cat retinal ganglion cells. J Neurophysiol 28:833-849.

Schneeweis DM, Schnapf JL (1995) Photovoltages of rods and cones in the macaque retina. Science 268:1053-1056.
Sharpe LT, Stockman A (1999) Rod pathways: the importance of seeing nothing. Trends Neurosci 22:497-504.

Slaughter MM, Miller RF (1981) 2-Amino-4-phosphonobutyric acid: a new pharmacological tool for retina research. Science 211:182-185.

Smith RG, Vardi N (1995) Simulation of the AII amacrine cell of mammalian retina: functional consequences of electrical coupling and regenerative membrane properties. Vis Neurosci 12:851-860.

Soucy E, Wang Y, Nirenberg S, Nathans J, Meister M (1998) A novel signaling pathway from rod photoreceptors to ganglion cells in mammalian retina. Neuron 21:481-493.

Stone C, Pinto LH (1993) Response properties of ganglion cells in the isolated mouse retina. Vis Neurosci 10:31-39.

Strettoi E, Dacheux RF, Raviola E (1990) Synaptic connections of rod bipolar cells in the inner plexiform layer of the rabbit. J Comp Neurol 295:449-466.

Thibos LN, Werblin FS (1978) The properties of surround antagonism elicited by spinning windmill patterns in the mudpuppy retina. J Physiol (Lond) 278:101-116.

Tsukamoto Y, Morigiwa K, Ueda M, Sterling P (2001) Microcircuits for night vision in mouse retina. J Neurosci 21:8616-8623.

Vaney DI (1994) Patterns of neuronal coupling in the retina. Prog Retin Eye Res 13:301-355.

Veruki ML, Hartveit E (2002) Electrical synapses mediate signal transmission in the rod pathway of the mammalian retina. J Neurosci 22:10558-10566.

Yoon M (1972) Influence of adaptation level on response pattern and sensitivity of ganglion cells in the cat's retina. J Physiol (Lond) 221:93-104.

Zhang J, Wu SM (2004) Connexin35/36 gap junction proteins are expressed in photoreceptors of the tiger salamander retina. J Comp Neurol 470:1-12. 